\title{
Five Years of Library Cooperation in the North Texas Region
}

\author{
Dr. Sampley is librarian, North Texas \\ State Teachers College, Denton.
}

A PROJECT in library cooperation in the North Texas region has extended from its inception in December 1942, to the publication in mimeographed form on Aug. I, 1948, of a completely revised North Texas Regional Union List of Serials. The publication of this list may appropriately be the occasion for a summary of the history of this project and a brief account of what it has accomplished.

In December 1942, a survey to determine whether it was feasible to organize a cooperative regional library enterprise was authorized by the presidents of North Texas State Teachers College, Southern Methodist University, Texas Christian University, and Texas State College for Women. Dr. A. F. Kuhlman, who carried out the survey, included in it also the public libraries of Dallas and Forth Worth and the library of Southwestern Baptist Theological Seminary. Thus three libraries in Fort Worth, two in Dallas, and two in Denton were brought into the enterprise. These libraries, located within an hour's driving distance of each other, are in the heart of the thickly settled North Texas region, and contained in 1943 a book stock of 810,000 volumes.

As a result of the survey, Dr. Kuhlman recommended the organization of the North Texas regional libraries with a coordinator or director; the mimeographing of a union list of serials; the expansion of the serial resources through planned, cooperative purchasing; cooperative acquisition of additional reference and bibliographic tools; a regional program for collection of government documents, newspapers, and manuscript collections; a union catalog of books; proper financial support; systematic planning for the strengthening of library resources; and local coordination of libraries. ${ }^{1}$

Of these recommendations two have been carried into effect: the mimeographing of a union list of serials, and the expansion of the serial resources through planned, cooperative purchasing. Some progress has been made in the local coordination of libraries. On the proposals involving the creation of some central library system, no steps have been taken. The fact that each of these libraries operates under a separate governing body is an obstacle which is not likely to be overcome in the near future.

The recommendation for the mimeographing of a union list of serials has been fully carried out. Each of the cooperating libraries sent in cards of their serial holdings to North Texas State Teachers College, where the master card catalog was established. From this catalog the first North Texas Regional Union List of Serials was published in mimeographed form in November of 1943. A supplement to this list was issued Jan. 15, 1945, and a second

${ }^{1}$ Kuhlman, A. F., The North Texas Regional Libraries: An Inquiry into the Feasibility and Desira. bility of Developing Them as a Cooperative Enterprise bility of Developing Them as a Cooperative Enterprise
(mimeographed), Nashville, Peabody Press, 1943, pp. $77 \cdot 82$. 
supplement was added Mar. 15, 1946. On Aug. I, I948, a completely revised union list was published. ${ }^{2}$

In the original Union List, Dr. W. Stanley Hoole, the editor, compiled the following table of titles held in the region:

The growth in serial holdings over the period from November 15, 1943, to June
I, 1948 , is indicated in Table III.

These rates of increase, ranging from 49 to 85 per cent, must be attributed in great measure to the stimulus of the regional project.

Not only have the libraries rapidly increased their holdings in serials; they have also made a concerted effort to eliminate

Table $\mathrm{I}^{3}$

Titles in the Region

\begin{tabular}{|c|c|c|c|c|c|}
\hline & (I) & (2) & (3) & (4) & (5) \\
\hline Held by: & $\begin{array}{l}\text { Complete } \\
\text { Closed } \\
\text { Files }\end{array}$ & $\begin{array}{l}\text { Incomplete } \\
\text { Files }\end{array}$ & $\begin{array}{c}\text { Complete } \\
\text { \& Current } \\
\text { Files }\end{array}$ & $\begin{array}{c}\text { Total } \\
\text { Columns } \\
\text { I-3 }\end{array}$ & $\begin{array}{c}\text { Titles } \\
\text { Rec'd } \\
\text { Currently }\end{array}$ \\
\hline 7 libraries & & II & & II & 4 \\
\hline 6 libraries & & $5 \mathrm{I}$ & 3 & 54 & $5^{8}$ \\
\hline 5 libraries & 3 & II 3 & 7 & 123 & 70 \\
\hline 4 libraries & 7 & 222 & 19 & 248 & 131 \\
\hline 3 libraries & $\mathrm{I}_{4}$ & $4^{18}$ & 46 & 478 & $18 \mathrm{I}$ \\
\hline 2 libraries & 68 & 773 & $9^{2}$ & 9.33 & 295 \\
\hline I library & 385 & 2406 & 395 & 3186 & 834 \\
\hline Totals & $606^{*}$ & $7042^{*}$ & $846^{*}$ & $8494^{*}$ & $3217^{*}$ \\
\hline
\end{tabular}

* Obtained by multiplying the figures in each separate bracket by the number of institutions opposite, and totaling.

An analysis of holdings of serials as of duplication of rarely-used material. A comJune I, I948, appears below : mittee of faculty representatives from North

Table II

Titles in the Region, June I, 1948

\begin{tabular}{|c|c|c|c|c|c|}
\hline & (I) & (2) & (3) & (4) & (5) \\
\hline Held by: & $\begin{array}{l}\text { Complete } \\
\text { Closed } \\
\text { Files }\end{array}$ & $\begin{array}{l}\text { Incomplete } \\
\text { Files }\end{array}$ & $\begin{array}{l}\text { Complete } \\
\text { \& Current } \\
\text { Files }\end{array}$ & $\begin{array}{c}\text { Total } \\
\text { Columns } \\
\text { I-3 }\end{array}$ & $\begin{array}{c}\text { Titles } \\
\text { Rec'd } \\
\text { Currently }\end{array}$ \\
\hline 7 libraries & & II & & II & 13 \\
\hline 6 libraries & I & 66 & 8 & 75 & 94 \\
\hline 5 libraries & 4 & 165 & 15 & 184 & 109 \\
\hline 4 libraries & 19 & $34^{2}$ & $4 \mathrm{I}$ & 402 & 168 \\
\hline 3 libraries & 29 & 609 & 64 & 702 & 238 \\
\hline 2 libraries & 119 & $105^{8}$ & 169 & I 346 & 429 \\
\hline I library & 573 & 3373 & $74^{8}$ & 4694 & 1378 \\
\hline Totals & $1000^{*}$ & $9982^{*}$ & $1565^{*}$ & $12,547^{*}$ & $4^{822} *$ \\
\hline
\end{tabular}

- Obtained by multiplying the figures in each separate bracket by the number of institutions opposite, and totaling.

${ }^{2}$ North Texas Regional Union List of Serials (mimeographed), Revised Edition, edited by Arthur M. Sampley and Louise Evans, Denton, Tex., North Texas State Teachers College, Aug. I, 1948.

${ }^{3}$ North Texas Regional Union List of Serials (mimeographed), edited by W. Stanley Hoole, Denton, Tex., North Texas State Teachers College, 1943, p. x.
Texas State Teachers College, Southern Methodist University, Texas Christian University, and Texas State College for Women met in the spring and summer of 
Table III

Increase in Serial Holdings

\begin{tabular}{|c|c|c|c|}
\hline & 1943 & $194^{8}$ & $\begin{array}{l}\text { Per Cent } \\
\text { Increase }\end{array}$ \\
\hline Complete Closed Files & 606 & 1000 & 65 \\
\hline Incomplete Files & 2406 & 3373 & 49 \\
\hline Complete and Current Files & 846 & I 565 & 85 \\
\hline Titles Rec'd Currently & 3217 & 4822 & 50 \\
\hline
\end{tabular}

I 944 and drew up a master list of serials to be acquired for the region as a whole. Each of these four libraries was assigned a certain number of files for which it was to fill in the gaps not held in the region. In the three-year period from July I, I945, through June $30,1948, \$ 40,000$ was spent by these four libraries in completing files for the region. None of this sum was spent to duplicate materials already held.

While this procedure strengthened the library resources of the region and reduced duplication in certain files, it did not reduce the total amount of duplication, which, as Table IV shows, has slightly increased.

At first glance it may appear that the regional project has had no effect in keeping down duplication, but this conclusion fails to take into account the probability that without cooperation the increase in duplication would have been considerably greater. All the libraries are growing rapidly and are making up for a late start in acquiring materials. The two public libraries have similar clienteles, and the four colleges and universities have similar curricula. Thus if the latter, all of which are members of the Southern Associaiton of Colleges and Secondary Schools, had files of all the periodicals recommended by the Association, ${ }^{4}$ the amount of duplication would be very much greater than it is. It is nevertheless true that more careful planning could reduce the acquisition of rarely-used files by more than one library.

One of the recommendations which has borne fruit is that calling for greater local cooperation in utilizing library resources. In Denton, for example, students of each of the two state-owned institutions have full use of the library facilities of both colleges. The result is that the library resources available to the students in each institution have been increased by not less than fifty per cent, ${ }^{5}$ without the cumbersome process of interlibrary loans.

\section{(Continued on page 68)}

4 Southern Association of Colleges and Secondary Schools, Commission on Institutions of Higher Education, The Classified List of Reference Books and Periodicals for College Libraries, Revised Edition, 1947, pp. 83-105.

${ }^{5}$ The total number of books available would be increased by a much greater per cent, but there is considerable duplication of titles. A comparison of 505 books from North Texas State Teachers College and 503 books from Texas State College for Women showed in 1943 that 159 of the N.T.S.T.C. books were duplicated at T.S.C.W., and that 224 of the T.S.C.W. books were duplicated" at N.T.S.T.C. "See Kuhlman, op. cit., p. 24 .

Table IV

Duplication of Files, I 943 , 1948

\begin{tabular}{|c|c|c|c|c|}
\hline \multirow[b]{2}{*}{ Titles Held By } & \multicolumn{2}{|c|}{1943} & \multicolumn{2}{|c|}{$194^{8}$} \\
\hline & $\begin{array}{c}\text { Number of } \\
\text { Titles }\end{array}$ & Percentage & $\begin{array}{c}\text { Number of } \\
\text { Titles }\end{array}$ & Percentage \\
\hline $\begin{array}{l}\text { I library } \\
2 \text { libraries } \\
3 \text { libraries } \\
4 \text { libraries } \\
5 \text { libraries } \\
6 \text { libraries } \\
7 \text { libraries }\end{array}$ & $\begin{array}{r}2902 \\
841 \\
444 \\
282 \\
170 \\
119 \\
16\end{array}$ & $\begin{array}{r}60.8 \\
17.6 \\
9.3 \\
5.9 \\
3.6 \\
2.5 \\
.3\end{array}$ & $\begin{array}{r}3796 \\
1196 \\
687 \\
455 \\
253 \\
169 \\
27\end{array}$ & $\begin{array}{r}57.7 \\
18.2 \\
10.4 \\
6.9 \\
3.8 \\
2.6 \\
.4\end{array}$ \\
\hline Totals & 4774 & 100.0 & $65^{8} 3$ & $1 \infty 0.0$ \\
\hline
\end{tabular}


members with regular assignments without seriously interferring with necessary day to day operations. An alternative, possible in larger institutions, would be to establish a research or laboratory unit where new ideas could be tested before they were put into regular operation. Perhaps we should go further than this and take a lesson from industry where a process may be tested in a pilot plant before it is attempted on a production basis. If this is to be our approach, the large library could make a small begin- ning by diverting staff time to experiments and pilot operations. However, a great deal more could be accomplished in a shorter time if libraries worked together in setting up an experimental laboratory for technical services. If we had as little as $\$ 50,000$ a year for five years (possibly less than 2 per cent of our annual expenditures for technical services), we might come out at the end of the five year period with new ideas and procedures capable of saving several times that amount annually.

\title{
Library Cooperation in North Texas
}

\author{
(Continued from page 26)
}

Administrative difficulties in maintaining the regional union list of serials have thus far not been great. The initial arrangement was made by a conference of the presidents of North Texas State Teachers College, Southern Methodist University, Texas Christian University, and Texas State College for Women. After the plans had been agreed upon, however, the direction of the work has been largely in the hands of the chief librarians of the cooperating libraries. The typing and mailing of extra cards for the central file and the maintaining of the master card catalog have been carried on by some score of librarians in addition to their regular duties. The mimeographing of the union list, however, has become a formidable problem whicn involved cutting eight hundred stencils for the revised edition. The cumulative burden of work, which is the nemesis of all union catalogs, may eventually force a new method of financial support or some other means of publishing the contents of the master card catalog.

The benefits of the North Texas regional project have been the strengthening of the serial resources of the region, the development of a plan of cooperative purchasing, and greater local cooperation in using library materials. Though the venture has not accomplished all that has been hoped for it, it has nevertheless made considerable progress.

\section{Correction}

Mr. Paul Alcorn of the University of Connecticut reports that the figures given in the printed sources in "Administrative Organization and Financial Support of Land-Grant College and University Libraries," IX, October 1948, p. 330, on which Table I was based are incorrect and incomplete. The enrollment, according to Mr. Alcorn, was 3355 , and library expenditures $\$ 60,100$. The per student expenditure for Connecticut was thus $\$ 17.91$ and the ratio $3.12 \%$. If these figures are used, the average per student expenditure would be $\$ 23.07$, and the average ratio $2.88 \%$. While these changes are of importance to the University concerned and do alter the general averages somewhat, the general conclusions of the article remain entirely valid. 